\title{
Carbon Sequestration in Broad Leaved Forests of Mid-Hills of Nepal: A Case Study from Palpa District
}

\author{
Bishnu P. Shrestha ${ }^{1}$
}

\begin{abstract}
This study was carried out to quantify total carbon sequestration in two broad leaved forests (Shorea and Schima-Castanopsis forests) of Palpa district. The inventory for estimating above and below ground biomass of forest was carried out using stratified random sampling. Biomass was calculated using allometric models. Soil samples were taken from soil profile upto $1 \mathrm{~m}$ depth for deep soil and up to bed rock for shallow soils at the interval of $20 \mathrm{~cm}$. Walkey and Black method were applied for measuring soil organic carbon. Total biomass carbon in Shorea and Schima-Castanopsis forest was found 101.66 and $44.43 t \mathrm{ha}^{-1}$ respectively. Soil carbon sequestration in Schima-Castanopsis and Shorea forest was found 130.76 and $126.07 \mathrm{tha}^{-1}$ respectively. Total carbon sequestration in Shorea forest was found 1.29 times higher than Schima-Castanopsis forest. The study found that forest types play an important role on total carbon sequestration.

यो अध्ययन पाल्पा जिल्लाको दुई फरक चौडापाते वनको कुल कार्वन संचितिकरणलाई निर्धारण गर्नकोलागि गरीएको हो। वनको जमिन माथि र तलको वायोमास अनुमान गर्नका लागि गरिएको सर्वेक्षण, नियमित स्याम्प्लीङ विधि अपनाई पूरा गरिएको थियो। बायोमास अलोमेट्रिक विधि अपनाई निकालिएको थियो। माटोको कार्वन मात्रा निर्धारण गर्नको लागि माटोको नमूनाहरु माटोको तहबाट लिइएको थियो, जसमा नमुना गहिरो माटोको लागि 9 मिटर गहिरोसम्म र सतही माटोको लागि भुईं ढुड़ासम्म २० सेन्टिमिटरको अन्तरमा लिइएको थियो। माटोको जैविक कार्वन मापनको लागि walkey and black विधि अपनाईएको थियो। साल र कटुस-चिलाउने वनको कुल कार्वन बायोमास ऋमानुसार 9०१.६६ र ४૪. ४३ टन प्रति हेक्टर पाइएको थियो। कुल कार्वन संचितिकरण चिलाउने कटुस वनमा भन्दा साल वनमा १. २९ सड्ख्याले बढ़ पाईएको थियो। यस अध्ययनले कुल कार्वन संचितिकरणमा वनको किसिमले प्रमुख भूमिका निर्वाह गाई भन्ने तथ्य उजागर गरेको छ।
\end{abstract}

Key Words: Carbon sequestration, Shorea forest, Schima-Castanopsis forest, Biomass carbon, Soil carbon

\section{Background}

Forests play an important role in the global carbon cycle. They can be both sources and sinks of carbon, depending on the specific management regime and activities (IPCC, 2000). It is believed that the goal of reducing carbon sources and increasing the carbon sink can be achieved efficiently by protecting and conserving the carbon pools in existing forests (Brown et al., 1996). Forest vegetation and soils share almost $60 \%$ of the world's terrestrial carbon (Winjum et al., 1992). Vegetation and soils are viable sinks of atmospheric carbon (C) and may significantly contribute to mitigation of global climate change (Bajracharya et al. 1998; Lal, 2004). Estimating stock of carbon under existing forest land, and their distribution within

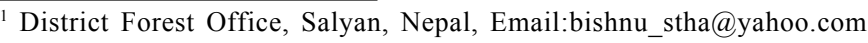


the soil profile, provides baseline data to enable us to project carbon sequestration over time. The carbon stock in a forest ecosystem can be broadly categorized into biotic (vegetative carbon) and pedologic (soil carbon) components. As trees grow, they sequester carbon in their tissues, and as the amount of tree biomass increases, the atmospheric $\mathrm{CO}_{2}$ is mitigated. About 43-50\% of the dry biomass of trees is carbon (Malhi et al., 2002; Negi et al, 2003). Soil contains the major part of carbon in terrestrial ecosystems. Trees, both in above and below ground biomass, continue to accumulate carbon until they reach maturity; at that point about half of the average tree's dry weight will be carbon (Anonymous, 2004). On the other hand, trees are long-lived plants that develop a large biomass, thereby capturing large amounts of carbon over a growth cycle of many decades. Thus, forests can capture and retain large amounts of carbon over long periods. These stocks are dynamic, depending upon various factors and processes operating in the systems, the most significant being land use, land-use changes, soil erosion, and deforestation (IPCC, 2000).

The carbon stock in forest vegetation varies according to geographical location, plant species and age of the stand (Van Noordwijk et al., 1997). Estimates of the biomass contained within forests are critical aspects of determination of the carbon loss associated with a wide range of land use and land-cover change processes. In order to assess the impact of deforestation and re-growth rates on the global carbon cycle, it is necessary to know the stocks of carbon as biomass per unit area for different forest types. The aboveground biomass and belowground root biomass both need to be measured to enable better calculations of total forest carbon (Hamburg, 2000).

Community Forestry has been accorded the highest priority of Nepal's forestry sector and has been widely acclaimed as a successful forest management approach. During the last 30 years of community forestry implementation, more than $25 \%$ of the national forest area is being handed over to more than 14,200 community forest user groups (Kanel, 2006). Forest users groups are protecting community forests for about last 30 years, but forest and soil inventory has been paid little attention regarding the carbon that it sequestrated, hence amount of soil and biomass carbon sequestrated is unknown. Fortunately, Nepal is first among the developing countries which have been selected by the World Bank as a member of the Forest Carbon Partnership Facility (FCPF), an innovative approach to financing efforts to combat climate change (www.worldbank.org). Nepal will receive initial funding from FCPF to Reducing Emissions from Deforestation and Forest Degradation (REDD). Therefore, this study aims to establish the base line information for carbon sequestration potential of different community managed broadleaved forests which is one of the key requirement of REDD, rarely done in Nepal. 


\section{Materials and methods}

\section{Study area}

The study was carried out in two different community managed forests (Bharkes, and Bajha) of Palpa district. Palpa lies between $27^{\circ} 14^{\prime}$ to $27^{0} 57^{\prime} \mathrm{N}$ latitude and $83^{\circ} 15^{\prime}$ to $83^{\circ} 45^{\prime} \mathrm{E}$ longitude, and is $300 \mathrm{~km}$ west from the capital city of Nepal. The district's terrain lies in the Mahabharata and Siwalik ranges. Bharkes and Bajha Community forest lie in the central part of Palpa district. Bharkes is a natural Shorea robusta forest which covers an area of 190 ha whereas Bhaja is natural Schima-Castanopsis forest which covers an area of 45.0 ha. The management practices implemented in these community forests are thinning and pruning.

\section{Sampling design}

Stratified random sampling was used for collecting data for plant biomass. Sixteen and eight sample plots were taken in Shorea robusta and Schima-Castanopsis forest respectively. The quadrate of size $20 \mathrm{~m} \times 25 \mathrm{~m}$ for trees ( $>30 \mathrm{~cm}$ dia), nested quadrate of size $10 \mathrm{~m} \times 10 \mathrm{~m}$ for poles (10-29.9 $\mathrm{cm}$ dia), $5 \mathrm{~m} \times 5 \mathrm{~m}$ for sapling ( $>5 \mathrm{~cm}$ dia) and $1 \mathrm{~m} \times 1 \mathrm{~m}$ for regeneration, grass and herb were laid out for collecting biophysical data. Tree species whose height is below than $1 \mathrm{~m}$ and diameter less than $5 \mathrm{~cm}$ were considered as shrub (Shrestha and Singh, 2008).

\section{Biophysical measurements}

Diameter at breast height of each tree within each plot was measured using diameter tape and height of each tree was estimated using Sunto Clinometer and Abney's level. For woody shrubs, diameter was measured at $15 \mathrm{~cm}$ above the ground level (Shrestha and Singh, 2008). All under storey bushes, grasses and herbaceous plants were clipped and the fresh weight of the samples were determined and representative sub sample of $300 \mathrm{gm}$ was taken to lab for oven dry.

\section{Soil sampling}

Profile was dug at centre part of the plot up to $1 \mathrm{~m}$ depth for deep soils and up to bed rock for shallow soils. Soil samples at different depths $(0-20 \mathrm{~cm}, 20-40 \mathrm{~cm}, 40-60 \mathrm{~cm}, 60-80$ $\mathrm{cm}$ and $80-100 \mathrm{~cm})$ were taken. A core ring sampler $(4.8 \mathrm{~cm}$ in dia. and $6 \mathrm{~cm} \mathrm{long})$ was used for bulk density.

\section{Data analysis}

\section{Aboveground biomass}

The logarithmic transformation of the algometric formulae were used in estimating volume and biomass. The total stem volume of each tree was calculated using the relationship developed by Sharma and Pukkala (1990). 
$\ln (\mathrm{V})=\mathrm{a}+\mathrm{b} * \ln (\mathrm{d})+\mathrm{c} * \ln (\mathrm{h})$

Where, $\mathrm{V}=$ the total stem volume with bark, $\mathrm{d}=$ the diameter at breast height $(\mathrm{cm}), \mathrm{h}=$ the tree height (m), and a, b, \& c are species specific constants shown in Table-1.

Table 1: Parameter $\mathrm{a}, \mathrm{b}$ and $\mathrm{c}$, and $\mathrm{R}^{2}$ for major tree species

\begin{tabular}{|l|l|l|l|l|l|}
\hline SN & Types of Species & a & b & c & R2 \\
\hline 1 & Shorea robusta & -2.4554 & 1.9026 & 0.8352 & 98.3 \\
\hline 2 & Schima wallichii & -2.7385 & 1.8155 & 10.072 & 98.3 \\
\hline 3 & Miscellence in hills & -2.3204 & 1.8507 & 0.8223 & 97.7 \\
\hline
\end{tabular}

Source: Sharma and Pukkala, 1990

After calculating volume of the tree, it was multiplied by the dry density of the wood (Chaturvedi and Khanna, 1982) of the species to get the above ground biomass. The biomass of branches and leaves were estimated using 45 and $11 \%$ of the stem biomass respectively (Sharma, 2003).

\section{Under-growth biomass}

Oven dry biomass values for litter, under storey bushes and grasses were calculated using the following formula (Lasco et al., 2005):

$\operatorname{ODW}(\mathrm{t})=\frac{\mathrm{TFW}-(\mathrm{TFW} *(\mathrm{SFW}-\mathrm{SODW}))}{\mathrm{SFW}}$

Where,

$$
\begin{aligned}
& \text { ODW = Total oven dry weight }, \mathrm{TFW}=\text { Total fresh weight } \\
& \text { SFW = Sample fresh weight, } \mathrm{SODW}=\text { Sample oven dry weight }
\end{aligned}
$$

The biomass of woody perennial shrubs was calculated using the equation developed by Hasse and Hasse (1995):

$\mathrm{Y}=\mathrm{a} \mathrm{D}^{\mathrm{b}}$

Where $\mathrm{Y}$ is the total dry biomass $(\mathrm{kg}), \mathrm{D}$ is the dia. $15 \mathrm{~cm}$ above the ground $(\mathrm{cm})$ and $a$ and $b$ are constants whose values were considered as -4.264 and 1.016 respectively, and with a correction factor of 1.0232 (Hasse and Hasse, 1995).

\section{Belowground biomass}

For the study, following relationship suggested by FAO (2000) was used for estimating the root biomass. 


\section{- For broad leaved vegetation}

Below ground biomass $=0.30 \mathrm{x}$ above ground biomass

\section{- Soil organic carbon (SOC)}

The Walkey-Black method was applied for measuring the soil organic carbon (McLean, 1982). Total soil organic carbon was calculated using the formula given below (Awasthi et al., 2005).

SOC $=$ Organic carbon content $\%$ x soil bulk density $\left(\mathrm{kg} / \mathrm{m}^{3}\right) \times$ thickness of horizon $(\mathrm{m})$

\section{- Bulk density}

Oven dry weight of soil samples determined for moisture correction. The dried soil then was passed through a $2 \mathrm{~mm}$ sieve, the sieved soil was weighed and volume of stones was recorded for stone correction. Following formula was used to calculate the bulk density using stone correction (Pearson et al., 2005).

$$
\text { Bulk density }\left(\mathrm{g} / \mathrm{cm}^{3}\right)=\frac{\text { Oven dry mass }\left(\mathrm{g} / \mathrm{cm}^{3}\right)}{\text { Core volume }\left(\mathrm{cm}^{3}\right)-\frac{\text { Mass of coarse fragments }(\mathrm{g})}{\text { Density of rock fragment }\left(\mathrm{g} / \mathrm{cm}^{3}\right)}}
$$

Where, the coarse fragments are $>2 \mathrm{~mm}$. The density of rock fragments is $2.65 \mathrm{~g} / \mathrm{cm}^{3}$.

\section{Estimation of net carbon content}

Total carbon was taken to be $43 \%$ of the biomass (Negi et al., 2003). The following formulae were used for computing total above and below ground biomass organic carbon.

Total above ground biomass organic carbon $=($ total above ground biomass of tree + total under storey biomass + shrub biomass) $* 43 \%$

And,

Total belowground biomass organic carbon $=($ total root biomass of tree $) * 43 \%+$ total soil organic carbon.

\section{Results and discussion}

\section{Properties of forest stand}

The mean diameter (14.27 cm) of the stand was high in Bajha (Schima-Castanopsis) forest and but large tree (diameter $39.0 \mathrm{~cm}$ and height $15.1 \mathrm{~m}$ ) was observed in Bharkes (Shorea robusta) forest (Table-2). Tree density was high in Bharkes (Shorea robusta) forest (3,057 trees/ha). The Bajha (Schima-Castanopsis) forest contained relatively smaller stands (1,237 trees/ha) compared to Shorea forest types (Table-2). 
Table 2: Properties of forest stand

\begin{tabular}{|l|c|c|c|c|c|c|c|}
\hline \multirow{2}{*}{ Types of Forest } & \multirow{2}{*}{$\begin{array}{c}\text { No. of } \\
\text { stem/ha }\end{array}$} & \multicolumn{3}{|c|}{ Diameter $(\mathbf{c m})$} & \multicolumn{3}{c|}{ Height (m) } \\
\cline { 3 - 8 } & & Mean & Min. & Max. & Mean & Min. & Max. \\
\hline Shorea Forest & 3,057 & 11.11 & 5.0 & 39.0 & 9.75 & 3 & 15.1 \\
\hline Schima-Castanopsis Forest & 1,237 & 14.27 & 5.0 & 24.50 & 10.03 & 4.1 & 13.5 \\
\hline
\end{tabular}

\section{Aboveground biomass estimation}

The biomass of tree and undergrowth vegetation varies with species, aspect and elevation. Result showed that aboveground tree biomass was found high in Shorea forest (177.24 \pm $38.88 \mathrm{tha}^{-1}$ ) and low in Schima-Castanopsis forest $\left(76.65 \pm 15.78 \mathrm{tha}^{-1}\right)$ (Table 3). Total aboveground tree biomass was in the order of Shorea forest $>$ Schima-Castanopsis forest. Undergrowth biomass was high in Shorea forest $\left(6.05 \pm 1.26 \mathrm{t} \mathrm{ha}^{-1}\right)$ and low SchimaCastanopsis forest $\left(3.75 \pm 0.52 \mathrm{tha}^{-1}\right)$.

Table 3: Distribution of aboveground biomass in two broadleaved forests

\begin{tabular}{|l|c|c|c|c|c|c|}
\hline \multirow{2}{*}{ Types of Forest } & \multicolumn{2}{|c|}{ Tree biomass $\left(\mathbf{t ~ h a ̈ ~}^{-1}\right)$} & \multicolumn{2}{|c|}{$\begin{array}{c}\text { Undergrowth biomass } \\
\left(\mathbf{t ~ h a}^{-1}\right)\end{array}$} & \multirow{2}{*}{$\begin{array}{c}\text { Total } \\
\left(\mathbf{t ~ h a}^{-1}\right)\end{array}$} & No. of plots \\
\cline { 2 - 6 } & Mean & SE & Mean & SE & 183.29 & 16 \\
\hline Shorea Forest & 177.24 & 38.88 & 6.05 & 1.26 & 80.4 & 8 \\
\hline Schima-Castanopsis Forest & 76.65 & 15.78 & 3.75 & 0.52 & 80.4 \\
\hline
\end{tabular}

\section{Aboveground carbon sequestration}

Total aboveground carbon sequestration was high in Shorea forest $\left(78.80 \mathrm{t} \mathrm{ha}^{-1}\right)$ and low in Schima-Castanopsis forest $\left(34.55 \mathrm{tha}^{-1}\right)$ (Table 4). Larger vegetation carbon sequestration was found in Shorea forest and smaller sequestration in Schima-Castanopsis forest, which is related to the size and height of tree stands and tree density. The tree density and tree size (dbh and height) were higher in Shorea forest compared to Schima-Castanopsis forest. Various factors affect ecosystem carbon stocks, including net primary productivity of plants and biomass decomposition (Shrestha and Lal, 2006). Net primary productivity differs according to vegetation type, age of the stand, and the surrounding environment (Shrestha and Singh, 2008).

Table 4: Aboveground carbon sequestration in two broadleaved forests

\begin{tabular}{|c|c|c|c|c|c|}
\hline \multirow{2}{*}{ Types of Forest } & \multicolumn{4}{|c|}{ Carbon Sequestration $\left(\mathrm{t} \mathrm{ha}^{-1}\right)$ by } & \multirow{2}{*}{$\begin{array}{l}\text { Total above Carbon } \\
\text { Sequestration (t ha })\end{array}$} \\
\hline & Stem & Branch & Leaf & Undergrowth & \\
\hline Shorea Forest & 48.85 & 21.98 & 5.37 & 2.60 & 78.80 \\
\hline $\begin{array}{l}\text { Schima-Castanopsis Forest } \\
\text { Schat }\end{array}$ & 21.12 & 9.50 & 2.32 & 1.61 & 34.55 \\
\hline
\end{tabular}




\section{Root biomass and carbon sequestration}

Root biomass was high in Shorea forest (53.17 tha $\mathrm{th}^{-1}$ ) and low in Bajha CF (22.99 tha $\left.\mathrm{t}^{-1}\right)$. Similarly, root carbon sequestration was found high in Shorea forest $\left(22.86 \pm 5.01 \mathrm{tha}^{-1}\right)$ and low in Schima-Castanopsis forest $\left(9.88 \pm 2.03 \mathrm{tha}^{-1}\right)$ (Table 5).

Table 5: Root biomass and carbon sequestration by different broadleaved forests

\begin{tabular}{|l|c|c|c|c|}
\hline Types of Forest & Root Biomass $\left(\mathbf{t ~ h a ̈}^{\mathbf{1}}\right)$ & $\begin{array}{c}\text { Carbon Sequestration by } \\
\text { Root (t hä }\end{array}$ & \multicolumn{2}{|c|}{ SE Mean No. of Plots } \\
\hline Shorea Forest & 53.17 & 22.86 & 5.01 & 16 \\
\hline Schima-Castanopsis Forest & 22.99 & 9.88 & 2.03 & 8 \\
\hline
\end{tabular}

\section{Soil carbon sequestration}

\section{- Bulk density}

There was large variation in the bulk density $(\mathrm{Bd})$ with respect to depth in the forest soils. There was a gradual increase in the Bd with increase in soil depth in different aspect and elevation. The range of bulk density in two broadleaved forests based on the entire profile $(0-100 \mathrm{~cm})$ depths is shown in Table 6. The minimum $\mathrm{Bd}\left(0.89 \pm 0.057 \mathrm{t} \mathrm{m}^{-3}\right)$ was found at the top soil (0-20 cm) in Schima-Castanopsis while maximum Bd $\left(1.148 \pm 0.078 \mathrm{t} \mathrm{m}^{-3}\right)$ at the depth of 80-100 cm in Shorea forest (Table 6).

Table 6: Bulk density in two broadleaved forests

\begin{tabular}{|l|l|l|l|l|}
\hline \multirow{2}{*}{ Soil Depth (cm) } & \multicolumn{2}{|l|}{ Shorea Forest } & \multicolumn{2}{l|}{ Schima-Castanopsis Forests } \\
\cline { 2 - 5 } & Mean & SE & Mean & SE \\
\hline $0-20$ & 0.95 & 0.075 & 0.89 & 0.057 \\
\hline $20-40$ & 1.01 & 0.056 & 0.98 & 0.086 \\
\hline $40-60$ & 1.046 & 0.068 & 1.01 & 0.086 \\
\hline $60-80$ & 1.132 & 0.047 & 1.06 & 0 \\
\hline $80-100$ & 1.148 & 0.078 & 1.19 & 0 \\
\hline
\end{tabular}

\section{- Soil organic carbon (SOC)}

The soil organic carbon in forest soil depends upon forest types, climate, moisture, temperature and types of soil. The SOC was higher at the upper layers and gradually decreased in the soil depth. The Table 7 shows the depth wise distribution of SOC stock in different forests. The maximum SOC $\left(47.26 \pm 2.40 \mathrm{tha}^{-1}\right)$ was found at the top soil $(0-20 \mathrm{~cm})$ in SchimaCastanopsis forest and minimum SOC $\left(14.96 \pm 2.736 \mathrm{tha}^{-1}\right)$ at the depth of 80-100 cm in Shorea forest (Table-7). The total SOC was high in Schima-Castanopsis forest (130.76 t $\left.\mathrm{ha}^{-1}\right)$ and low in Shorea forest $\left(126.07 \mathrm{t} \mathrm{ha}^{-1}\right)$. These results could partly be assigned to the profile depth. This showed that spatial distribution of different forest lands is reflected in SOC stock. 
Table 7: Soil organic carbon $\left(\mathrm{t} \mathrm{ha}^{-1}\right)$ in two broadleaved forests

\begin{tabular}{|l|l|l|l|l|l|l|}
\hline \multirow{2}{*}{ Soil Depth (cm) } & \multicolumn{3}{|l|}{ Shorea Forest } & \multicolumn{3}{|l|}{ Schima-Castanopsis Forest } \\
\cline { 2 - 7 } & N & Mean & SE & N & Mean & SE \\
\hline $0-20$ & 16 & 38.02 & 1.917 & 8 & 47.26 & 2.40 \\
\hline $20-40$ & 16 & 30.11 & 2.218 & 8 & 27.55 & 1.88 \\
\hline $40-60$ & 11 & 24.17 & 3.174 & 7 & 20.90 & 2.23 \\
\hline $60-80$ & 9 & 18.81 & 2.243 & 2 & 18.65 & 1.66 \\
\hline $80-100$ & 6 & 14.96 & 2.736 & 2 & 16.40 & 0.31 \\
\hline
\end{tabular}

$\mathrm{N}=$ number of samples

\section{Total carbon sequestration}

Total carbon sequestration was sum of aboveground carbon, root carbon and soil organic carbon.

Total carbon sequestration was found high in Shorea forest $\left(227.73 \mathrm{tha}^{-1}\right)$ and low in SchimaCastanopsis forest (175.19 tha $\left.{ }^{-1}\right)$ (Table-8).

Total Carbon sequestration in Shorea forest was found 55\% in soil, 35\% in aboveground and 10\% in root (Table-8). Similarly, Carbon sequestration in Schima-Castanopsis forest was found $74 \%$ in soil, $20 \%$ in aboveground and $6 \%$ in root (Table- 8 ).

Table 8: Total carbon sequestration in two broadleaved forests

\begin{tabular}{|l|l|l|}
\hline \multirow{2}{*}{ Carbon Sequestration } & \multicolumn{2}{|c|}{ CS $\left(\mathbf{t ~ h a} \mathbf{~}^{-1}\right)$ in } \\
\cline { 2 - 3 } & Shorea Forest & Schima-Castanopsis Forest \\
\hline Aboveground Carbon & $78.80(35 \%)$ & $34.55(20 \%)$ \\
\hline Root Carbon & $22.86(10 \%)$ & $9.88(6 \%)$ \\
\hline Soil Carbon & $126.07(55 \%)$ & $130.76(74 \%)$ \\
\hline Total & 227.73 & 175.19 \\
\hline
\end{tabular}

\section{Conclusion}

Total biomass carbon sequestration was higher in Shorea robusta forest and low in SchimaCastanopsis forest. The SOC sequestration was high in Schima-Castanopsis and low in Shorea forest. Average soil carbon comprised $64.5 \%$ of carbon. Thus, total carbon sequestration in forest vegetation varies depending on forest types. Both forests are good for biomass and soil carbon sequestration. Soil offers a more promising sink for carbon over longer time period under forest cover. 


\section{Acknowledgements}

I am thankful to Community Based Natural Forest and Tree Management in the Himalayas (ComForM) project, Institute of Forestry, Pokhara for financial support. I like to express my thanks to Yajnamurti Khanal, Bimal Shrestha and Sanjay Shrestha for their help during my entire field work.

\section{Reference}

Anonymous, 2004. Forest Carbon Sequestration. Catalyst 3: 1- 4.

Awasthi, K. D., Singh, B. R., Sitaula, B. K. 2005. Profile carbon and nutrient levels and management effect on soil quality indicators in the Mardi watershed of Nepal. Acta agriculture Scandinavia Section B-Soil and Plant, 55:192-204.

Bajracharya, R. M., Lal, R., Kimble, J. M. 1998. Soil organic carbon distribution in aggregates and primary particle fractions as influenced by erosion phases and landscape position. In Soil Processes and the Carbon Cycle Lal R., Kimble J., Follett R. and Stewart B.A. (eds.). CRC Press, Boca Raton, Florida, 353-367.

Brown, S., Sathaye, J., Cannell, M., Kauppi, P. E. 1996. Mitigation of carbon emissions to the atmosphere by forest management. Complete Forestry Review 75(1):80-91.

FAO, 2000. Carbon sequestration options under the clean development mechanism to address land degradation. World Soil Resources Reports 92.

Hamburg, S. P., 2000. Simple rules for measuring changes in ecosystem carbon in forestryoffset projects. Miti Adapt Strat Global Change 5(1):25-37.

Hasse, R., Hasse, P., 1995. Aboveground biomass estimates for invasive trees and shrubs in the pantanal of Mato-Grosso, Brazil. For Ecol Manage 73 (1-3): 29-35.

IPCC, 2000. The Intergovernmental Panel on Climate Change, Special Report on Land Use, Land-Use Change and Forestry. Cambridge University Press, Cambridge, UK.

Kanel, K. R., 2006. "Current Status of Community Forestry in Nepal" submitted to Regional Community Forestry Training Center for Asia and the Pacific Bangkok, Thailand 26p.

Lal, R., 2004. Soil Carbon Sequestration to mitigate climate change. Geoderma 123(12):1-22.

Malhi, Y., Meir, P., Brown, S., 2002. Forests, Carbon and Global climate. Phil. Trans. R. Soc. Lond. A 360, 1567 - 1591.

McLean, E.O., 1982. Soil pH and lime requirement. In Methods of soil analysis part 2: Chemical and microbiological properties Page, A. L., Miller, R. M., Keeney, D. R., (eds.), 2nd edn. American Soc. of Agron. Monograph No. 9, ASA-SSSA, Inc., Madison, WI, USA, 199-224. 
Negi, J. D. S., Manhas, R. K., Chauhan, P. S., 2003. Carbon allocation in different components of some tree species of India: a new approach for carbon estimation. Curr Sci India 85 (11): 1528-1531.

Pearson, T.R.H., Brown, S., Ravindranath, N.H., 2005. Integrating Carbon Benefit Estimates into GEF Projects. Capacity Development and Adaptation Group Guidelines. United Nations Development Programme Global Environment Facility, Global Environment Facility, Bureau of Development Policy, New York, USA.

Sharma, E.R., Pukkala, J., 1990. Volume tables for forest trees of Nepal, 48. Ministry of Forest and Soil Conservation, Forest Survey and Statistics Division, Kathmandu, Nepal 84p.

Sharma, R.P., 2003. Relationship between tree dimensions and biomass, sapwood area, leaf area and leaf area index in Alnus nepalensis D. Don in Nepal, Agricultural University of Norway (NLH), Aas.

Shrestha, B.M., Singh, B.R., 2008. Soil and Vegetation Carbon Pools in a Mountain Watershed of Nepal. Nutrient Cycling in Agro ecosystems 81:179-191 (DOI 10.1007/s10705-007-9148-9).

Shrestha, R.K., Lal, R., 2006. Ecosystem carbon budgeting and soil carbon sequestration in reclaimed mine soil. Environ Int 32(6):781-796.

Van Noordwijk, M., Cerri, C., Woomer, P.L., Nugroho, K., Bernoux, M., 1997. Soil carbon dynamics in the humid tropical forest zone. Geoderma 79(1-4):187-225.

Winjum, J.K., Dixon, R.K., Schroeder, P.E., 1992. Estimating the global potential of forest and agro forestry management practices to sequester carbon. Water Air Soil Pollut 64(1-2):213-227. 